\title{
The Construction of a New College English M-Learning Environment
}

\author{
Songbin $\mathrm{BaO}^{1}$, Wenting $\mathrm{Xu}^{1}$ and Fanqi Meng ${ }^{2}$ * \\ ${ }^{1}$ School of Foreign Language, Northeast Electric Power University, Jilin 132012, China; \\ ${ }^{2}$ School of Computer Science, Northeast Electric Power University, Jilin 132012, China. \\ * Corresponding author
}

Keywords: Computer-assisted language learning; College English; M-learning environment; App software.

\begin{abstract}
College English is a very important course in many universities in China. In order to further improve the teaching effect of College English, a new M-learning environment which is based on multiple Apps has been constructed. This article firstly analyzes the necessity of constructing a new M-learning environment for College English from the aspects of curriculum setting, teaching mode and teaching evaluation. Then the main functions of the new M-learning environment are defined in terms of students' M-learning behaviors and teachers' requirements. On this basis, several Apps are selected for College English M-learning and a set of strategies are developed to integrate these Apps together to form a new College English M-learning environment. Practical application showed that the new M-learning environment played a role in computer-assisted language learning. It significantly lengthened students' time for learning College English and improved teaching efficiency.
\end{abstract}

\section{Introduction}

College English is a very important course in many universities in China, which usually covers four semesters with 224 academic hours for 14 credits. General education courses, such as College Chinese, only take one semester with about 32 academic hours for 2 credits. However, the academic hours spent in College English classes still fall short of what Chinese students need [1]. Although the emergence of M-learning can theoretically solve the insufficiency in learning time, we still need the assistance of a specific learning environment so that students can make good use of time slots in their spare time and combine M-learning with traditional classroom appropriately so as to truly improve the consequence of College English teaching [2].

The rest of this paper is arranged as follows: Section 2 analyzes the necessity of constructing a new M-learning environment for College English from the aspects of curriculum setting, teaching mode and teaching evaluation. Section 3 defines the main functions of the new M-learning environment in terms of students' M-learning behaviors and teachers' requirement. On this basis, section 4 introduces the practical procedure. We select several Apps for College English M-learning and developed a set of strategies to integrate these Apps together to form a new College English M-learning environment. Then the data show that using this new environment can lengthen students' time for learning College English and improve teaching efficiency. Section 5 is the conclusion.

\section{Necessity of Constructing a M-learning Environment}

“College English Teaching Requirements” issued by the Ministry of Education must be observed, which involves six aspects: teaching nature and objectives, teaching requirements, curriculum setting, teaching mode, teaching evaluation and teaching management. Among them, curriculum setting, teaching mode and teaching evaluation are the most obvious demands for a new College English M-learning environment [3].

\subsection{Curriculum setting.}

According to "College English Teaching Requirements", College English should be individualized no matter whether the curriculum is based on computer or classroom teaching. That is to say, on one hand, students with different learning basis and levels need to be considered and offered with appropriate learning platforms and development space. On the other hand, with regard to professional needs, fulfilling the foundation of “College English Teaching Requirements” should be accompanied by individualized learning. 


\subsection{Teaching mode.}

“College English Teaching Requirements" advocates a new teaching mode supported by information technology, especially network technology, so that English teaching and learning, to a certain extent, can move towards individualized and autonomous learning without being limited by time and place. A shift is advocated from teacher-centered, knowledge/skill-focused teaching concept and practice to student-centered teaching concept and practice, which not only teaches language knowledge and skill but also highlights practical ability and autonomous learning ability so as to cultivate students' life-time learning habits.

\subsection{Teaching evaluation.}

Teaching evaluation should include formative assessment and final assessment. "College English Teaching Requirements" recommends the forms of student self-assessment, student self-study record, learning record, interview and discussion and advocates student self-assessment, student mutual evaluation, teacher evaluation and evaluation by relevant departments. Therefore, the evaluation methods should be three-dimensional and multi-faceted.

The above three requirements are difficult to realize in the traditional College English course. First of all, traditional College English classrooms usually include 80 students. Second, College English teachers usually undertake more than two classes. Finally, each teacher teaches 20 academic hours a week. As a result, teachers have no time and energy to fix eyes on students with different learning bases and levels. Hence, it is difficult to evaluate each student in a three-dimensional and multi-leveled manner.

Fortunately, M-learning platform can play the following roles in supporting College English learning: (1) Students' learning methods can be so diversified that students can learn anytime and anywhere; (2) It is convenient to carry out individualized learning, which takes into account the characteristics of students' profession; (3) It is easy to convert into students' spontaneous and autonomous learning; (4) It can lengthen learning time, increase learning opportunities and make recording and evaluation more consistent and credible [4]. Therefore, it is necessary to construct a new College English M-learning environment in order to satisfy "College English Teaching Requirements".

\section{Functions of the New M-learning Environment}

\subsection{Patterns of students' m-learning}

Mastering the college students’ M-learning patterns can better design the new College English M-learning environment. According to a survey, $83.77 \%$ of college students think English is important. 82.32\% of college students have no more than 40 minutes to study English per day. The time for learning English is usually between 6:00-8:00 (54.55\%), 19:00-21:30 (34.24\%) and 21:30-23:30 (33.51\%). 79.27\% of college students want to conduct M-learning under the guidance of teachers. Students' favorite M-learning forms are listening to English songs (60.79\%), watching English movies (58.25\%) and looking up dictionaries (55.56\%). In addition, in the process of M-learning, $41.3 \%$ of learners feel visual tiredness and lack concentration. $35.9 \%$ believe that it is not easy to take notes while using online learning. $28.3 \%$ give the feedback that they tend to learn quickly and forget easily. 25\% express that they often lose the direction in the M-learning environment. In short, without the guidance of College English teachers and the support of a good M-learning environment, the efficiency of M-learning will be low with its effect mediocre [5].

In view of the above common phenomena, the construction of a new College English M-learning environment should take into account the following aspects: (1)The communication between teachers and students should be convenient so that teachers can guide students' M-learning. (2) The APP usage should be simple and easy so that students can focus on their study in the shortest time. (3) It should be avoided to present too much contents and resources in the system at one time, which may lead to students' learning anxiety. (4) M-learning resources should be mainly audio-visual. (5) Each study time should be between 5 and 10 minutes.

\subsection{Teachers' requirement}

The new learning environment should be able to help teachers realize individualized teaching. College students need the assistance offered by teachers in learning strategies, learning contents and learning 
resources, etc. Such kind of support should be interactive in that only through a series of conversations and feedback can better results be achieved [6-7]. Therefore, teachers are willing to use the M-learning platform to track and tutor students' learning, practice and review, while students also feel that teachers are within their fingertips. In other words, the platform can not only supervise and guide students' M-learning, but also enable students to get timely help, to the greatest extent, to eliminate students' negative emotions so as to achieve long-term learning.

A new learning environment should help teachers improve their work efficiency [8]. In order to achieve effective learning results, every student needs to be taught in accordance with their aptitude, which undoubtedly will take a lot of time and energy. Therefore, teachers hope that M-learning platforms can more accurately record the sequence of students' learning activities, automatically evaluate and analyze students' knowledge levels and learning habits so as to provide more targeted guidance and improve work efficiency.

\subsection{Functional modules for the new environment}

Based on the patterns for students' M-learning and teachers' requirement, we believe that the new College English M-learning environment should include the following functions: (1) Individualized learning; (2) Evaluation and feedback; (3) Learning management, as shown in Fig. 1. The individualized learning mainly provides learning contents in listening, speaking, reading, writing and translating in the form of text, video and audio. Students can choose learning contents in terms of their own needs. The evaluation and feedback mainly tests and evaluates students' ability in listening, speaking, reading, writing and translating. Learning management includes managing student information, learning content, assessment content and learning record, etc.

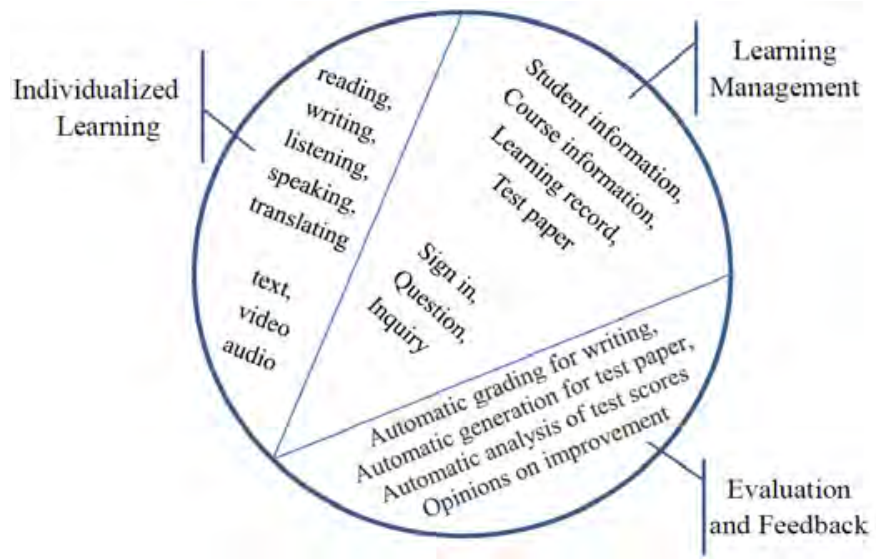

Fig. 1 Main Functions of the new College English M-learning Environment

\section{Practical Results and Analysis}

We set up a new College English M-learning environment by using WeChat, Super-Star Learning, Yasinda Platform and Pigai Website. The functions undertaken by each APP are shown in Table 1.

WeChat is the most commonly-used instant communication tool by teachers and students, which can minimize the possibility of not receiving notifications [1]. In addition, we set up WeChat groups based on College English classes and required that each student should send reading voices for no less than 5 minutes every day. This solves the problem of limited class time for everyone to practice oral English. Meanwhile, these voices will be temporarily stored by WeChat and teachers can listen to students' reading voices in spare time so as to give students guidance after class.

Table 1 Teaching Functions of APP Software

\begin{tabular}{ccc}
\hline App Name & Main Functions & Application Occasion \\
\hline Wechat & $\begin{array}{c}\text { Release notice, } \\
\text { oral practice and evaluation }\end{array}$ & outside class \\
\hline Super-Star Learning & $\begin{array}{c}\text { Classroom management, } \\
\text { reading, listening, translation } \\
\text { assessment }\end{array}$ & In class \\
\hline
\end{tabular}




\begin{tabular}{ccc}
\hline & Cont. to Table 1 & \\
\hline Yasinda Platform & $\begin{array}{c}\text { Reading, listening, } \\
\text { translation exercise } \\
\text { Writing exercise and } \\
\text { Pigai Website }\end{array}$ & outside class \\
& evaluation & outside class \\
\hline
\end{tabular}

Super-star Learning is a M-learning platform launched by Super-star Network. The platform offers many functions to facilitate teaching procedures. For example, we can use its check-in function to check students' attendance in class. It only takes about 2 minutes to finish this task, which used to take at least 10 minutes. We can input the questions of listening/reading comprehension into the platform in advance, and then conduct quizzes in class. The platform can automatically score students' test papers. In the past, teachers were required to print test papers and grade students' test papers one by one, which not only took a lot of time and but also wasted paper.

Yasinda Platform provides special training in listening, reading and translation. Each student is required to complete no less than 60 listening exercises, 60 reading exercises and 60 translation exercises each semester to improve their language skills.

Pigai Website can analyze problems of students’ writing in vocabulary, collocation, grammar and spelling and offer quick feedback and detailed suggestions for revision so as to help students realize their shortcomings and problems in writing. Therefore, students can make targeted learning and practice. Each student is required to complete no less than 5 essays per semester.

It should be emphasized that teachers should not only teach listening, speaking, reading, writing and translating in class, but also summarize students' M-learning, such as: make comments on students' compositions. Since there is still a difference between automatic and manual grading, a high grade composition is not necessarily a good composition.

Under the circumstances of the new College English M- learning environment, students' learning time and teachers' work efficiency have been greatly improved. Fig. 2 shows the comparison between traditional teaching environment and the new M-learning environment in the amount of listening, speaking, reading, writing and translating students are involved in one semester. Fig. 3 shows the comparison between traditional teaching environment and the new M-learning environment in the times of teacher' roll call, listening test, speaking test, reading test, writing test and translation test in one semester.

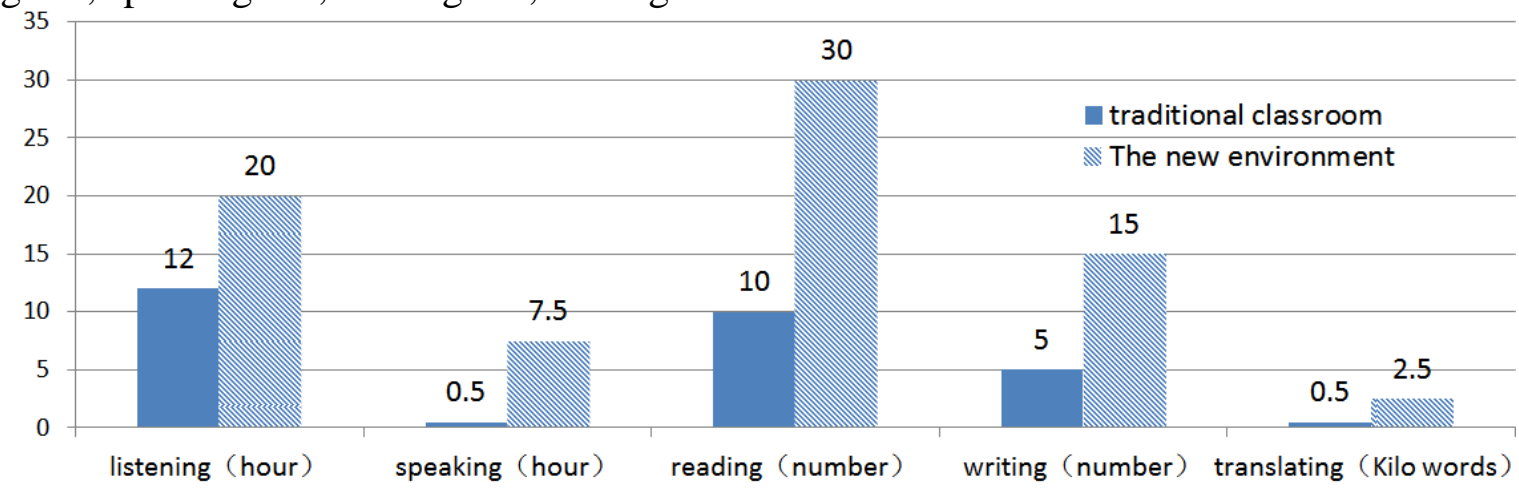

Fig. 2 The average amount of well-documented students learning in a semester

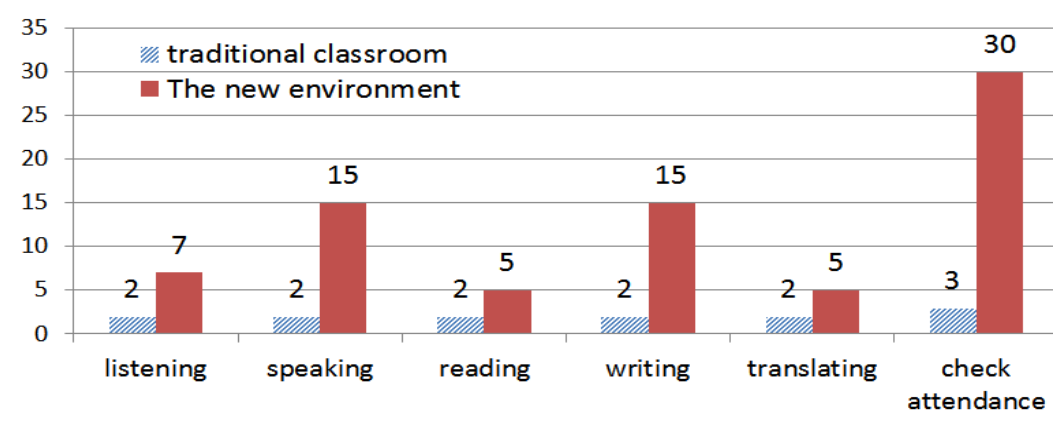

Fig. 3 Tests conducted by teachers in a semester 


\section{Conclusion}

This paper sets up a new M-learning environment for College English based on multiple APPs. The following problems have been solved with the support of the new environment:(1) There is no time to check students' attendance in every class; (2) Students are unwilling to practice oral English in class due to shyness; (3) The results of listening tests cannot be reported instantly in class; (4) Automatic composition scoring is not individualized enough, thus limits the improvement of students' writing ability. The usage of the new environment greatly increases students' opportunities to learn English in fragmented time and improves teachers' work efficiency, which is of great significance for improving students' English level.

\section{Acknowledgment}

This work is supported by the following projects: the "13th Five-Year" Social Science Project (JJKH20170117sk) of the Jilin Provincial Education Department; the Teaching Reform Project (JX201617) of Northeast Electric Power University; and the Graduate Education and Teaching Reform Research Project (YJG201704) of Northeast Electric Power University.

\section{References}

[1]. Jin W, Zhirui D. Research on Mobile Learning Model of College English Based on WeChat Platform[J]. Eurasia Journal of Mathematics, Science \& Technology Education, 2017, 13(8): 5847-5853.

[2]. Huang L. Acceptance of Mobile Learning in Classroom Instruction among College English Teachers in China Using an Extended TAM[C]// 2017 International Conference of Educational Innovation through Technology (EITT). IEEE, 2017: 283-287.

[3]. Xu J, Fan Y. The evolution of the college English curriculum in China (1985-2015): changes, trends and conflicts[J]. Language Policy, 2017, 16(3): 267-289.

[4]. Mei B, Brown G T L, Teo T. Toward an understanding of preservice English as a Foreign Language teachers' acceptance of computer-assisted language learning 2.0 in the People's Republic of China[J]. Journal of Educational Computing Research, 2018, 56(1): 74-104.

[5]. Heflin H, Shewmaker J, Nguyen J. Impact of mobile technology on student attitudes, engagement, and learning[J]. Computers \& Education, 2017, 107: 91-99.

[6]. Shen G R. Chinese College English Teachers’ Ability to Develop Students’ Informationized Learning in the Era of Big Data: Status and Suggestions[J]. EURASIA Journal of Mathematics, Science and Technology Education, 2018, 14(6): 2719-2729.

[7]. Jing X. Application of mobile learning system in phonetics teaching[C]//The 8th International Conference on E-Education, E-Business, E-Management and E-Learning. ACM, 2017: 19-23.

[8]. Fraga L M, Flores B B. Mobile learning in higher education[M]//Handbook of research on mobile technology, constructivism, and meaningful learning. IGI Global, 2018: 123-146. 